\title{
ANALYSING THE RELIABILITY OF WORKING PARTS OPERATING IN ABRASIVE SOIL PULP TAKING INTO CONSIDERATION CONFOUNDING FACTORS
}

\section{ANALIZA NIEZAWODNOŚCI ELEMENTÓW ROBOCZYCH FUNKCJONUJĄCYCH W GLEBOWEJ MASIE ŚCIERNEJ Z UWZGLĘDNIENIEM CZYNNIKÓW ZAKŁÓCAJĄCYCH*}

\begin{abstract}
This paper refers to the aspects of wear in structural materials used for the manufacture of working parts operating in abrasive soil pulp. Our study was conducted on six steel grades: Hardox 500 and Hardox 600, XAR 600, TBL Plus, B27 and $38 G S A, 13$ pad-welded layers and two types of carbide-based layers. The results obtained were used to analyse reliability and durability in terms of meeting the assumed abrasive wear limits. Analytical tools employed included multi-dimensional analyses, such as cluster analysis, correspondence analysis, and comparative analysis in a function of reliability with the use of the Mantel-Haenszel test. The latter method was used to study the influence of a confounding factor (change of the soil pulp type) on the reliability of the models determined.
\end{abstract}

Keywords: friction, abrasive wear, multi-dimensional analyses, reliability

\begin{abstract}
Praca poświęcona jest zagadnieniom związanych z zużywaniem materiałów konstrukcyjnych stosowanych do produkcji elementów roboczych funkcjonujacych w glebowej masie ściernej. Badania własne przeprowadzono dla sześciu rodzajów stali: Hardox 500 i Hardox 600, XAR 600, TBL Plus, B27 i 38GSA, 13 warstw napawanych oraz dwóch rodzajów warstw z węglikami. Uzyskane wyniki postużyty do przeprowadzenia analizy niezawodności i trwałości w aspekcie osiagnięcia założonych wartości granicznych zużycia ściernego. Jako narzędzia analityczne wykorzystano analizy wielowymiarowe takie, jak: analiza skupień, analiza korespondencji oraz analiza porównawcza funkcji niezawodności z zastosowaniem testu Mantela-Haenszela. Ostania z wymienionych metod postużyła do zbadania jak wpływa czynnik zakłócający (zmiana rodzaju masy glebowej), na wyznaczone modele niezawodności.
\end{abstract}

Stowa kluczowe: tarcie, zużycie ścierne, analizy wielowymiarowe, niezawodność.

\section{Introduction}

The performance of technical structures, determined by their technical condition, depends on the advancement of wear processes taking place during their operation. The problem of prediction in the course of service (time, path, number of cycles, etc.) until failure lies in the difficulty of the quantitative description of the severity of wear processes occurring in technical structures. For abrasive substances acting on the working parts of machinery, abrasive wear is considered the main cause of failures. If the wear is caused by normal (expected) service, then, for operation process control, it is essential to determine the wear limits and the estimated time of reaching them. Failing that, the objective of field tests (reliability tests) will be to identify the causes of excessive wear and to develop a method to reduce such wear.

Meeting the objective to reduce material wear in construction nodes is possible through reducing the intensity of destructive phenomena occurring in materials by proper shaping of the components, studying the relationships between chemical composition, microstructure and material properties, developing research methods for effective modelling of wear, and developing methods for describing phenomena and durability forecasting [12].

The process of working part wear in soil pulp belongs to the category of natural processes [11. 16]. In addition to uncontrollable processes which cannot be influenced, there are also controllable processes taking place. The controllability range depends on the knowledge of natural processes and the possibility to influence them. The problem of material wear in soil pulp is very complex and requires an interdisciplinary approach. Generally, the wear process is analysed based on its consequences. The primary objective in solving the problems is to adjust the material and structural solutions of working parts to the environmental forces, including the properties of abrasive pulp. The multitude of factors affecting the wear of working parts in the soil pulp means that, to date, no satisfactory descriptions have been provided for system-forming relationships between the working parts and environmental influences. Despite the random environmental influences and difficulties in creating comprehensive solutions, a rational choice of the structural and technical forms of working parts and service life planning can be done. To this end, complex experiments have to be carried out for various patterns of wearing out their usable resources in determined time and forces. This can be achieved by composing the relevant characteristics affecting the process. Material science delivers increasingly perfect construction materials which can be used to fabricate working parts for processing soil pulp [1]. However, the question arises here of whether a working part made of the same structural material should be used in all types of abrasive pulp. Determining the relationship between wear intensity and the property characterising the structural material concerned considerably simplifies the selection of proper material for specific soil forces. Available

(*) Tekst artykułu w polskiej wersji językowej dostępny w elektronicznym wydaniu kwartalnika na stronie www.ein.org.pl 
grades of steel, cast steel and cast iron with specifically constituted properties, pad-welding material and carbides may contain high levels of deficit alloy additives, thus making their use much more expensive. Therefore, it is necessary to study the effect of carbide-forming elements on the phase and structural composition, and the properties of materials in individual types of abrasive pulp.

The material selection criterion is chosen based on two factors, namely: achieving the appropriate hardness and forming a precisely defined phase composition of the heterogeneous pad-weld structure $[5,9,13]$. In the case of iron alloys, the carbide phases are mainly involved. This results in trends to increase the carbon percentage in pad-weld materials and to add strongly carbide-forming elements $(\mathrm{Nb}, \mathrm{B})[14,22]$. In addition to the volume percentage of carbides in the pad-weld material structure, the dimensions, shape and distribution are also important. The choice of carbides with specific properties has to take into account the relationships between $\mathrm{Fe}-\mathrm{Cr}-\mathrm{C}$ and carbide-forming elements. The most common carbides include $\mathrm{Fe} 3 \mathrm{C}$ (840-1000HV), Cr7C3 (1800HV), Cr2C3 (1500HV), WC (2400HV), VC (2800HV), Mo2C (1200HV), and TiC (3200HV). Using Fe-Cr-C alloys as a reference point is due to the fact that alloys whose main element is chromium are most commonly used and considered to be the most cost-effective. The most commonly used additives include $\mathrm{W}, \mathrm{Mo}, \mathrm{V}, \mathrm{B}$, and $\mathrm{Nb}$. For example, with the addition of boron, Ti2B, $\mathrm{FeB}, \mathrm{Cr} 2 \mathrm{BC}$, and M23(C, B)6 bromides and carbides can be formed.

Wear resistance also depends on a number of factors, the most significant of them being the content of elements, including the quantity and form of carbides, strength, elasticity of metallic matrix, and microstructure type. Analysis of the literature available $[1,2,3,6,7$, $15,21]$ indicates that the phase structure and pad-weld structure should be interpreted individually for the specific chemical components. The unambiguous and universal classification of pad-welding materials is difficult since those materials require proper choice due to their specific structures, depending on the conditions of use present. The

a)

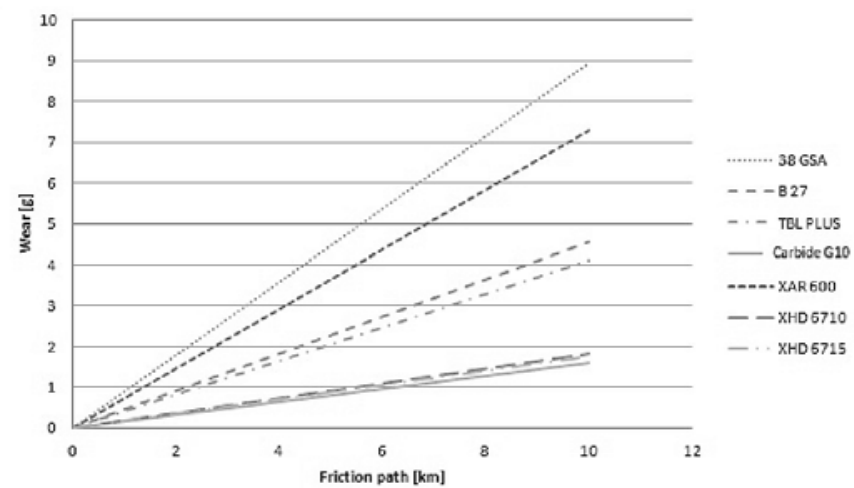

b)

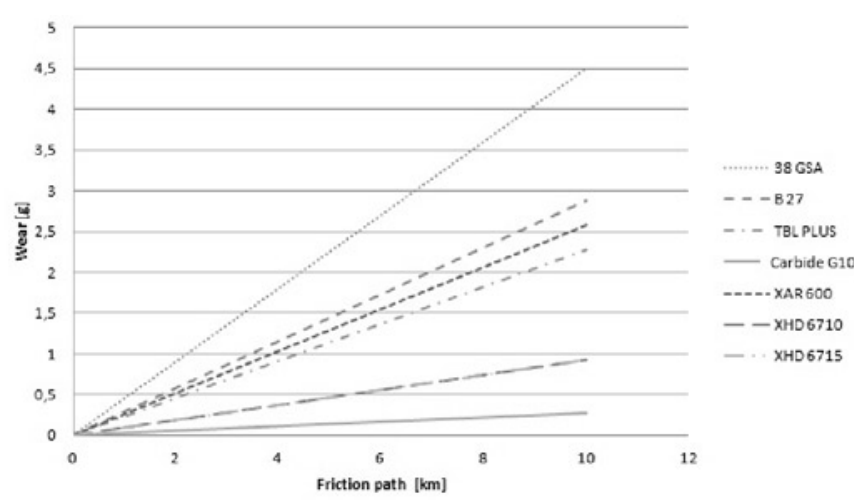

Fig. 1. Wear of the materials (specimens) with the area $750 \mathrm{~mm} 2$, a) in light clay, b) in loamy sand [12] waveforms presented (Fig. 1) indicate different material consumption in individual soil conditions.

Analysing the curves shown in Fig. 1, it can be noted that the soil type not only affects the wear rate, but also changes the resistance ranking of individual materials. In order to answer the question which of the materials can be considered similar and attributed with proper wear resistance properties (e.g. high, satisfactory, unsatisfactory resistance), various statistical methods are employed, from the basic ones, such as variance analysis and post-hoc tests [8], to multi-dimensional comparative analysis, which can be defined as methods for comparing objects described in terms of their properties, e.g. the discriminant, main component and cluster analysis $[8,10,12]$. From the standpoint of typical reliability, complementary to those methods may be the comparative methods of reliability function, utilising the following tests [18]:

- long-rank;

- Cox-Mantel;

- F Cox;

- Wilcoxon-Gehan;

- Peto-Peto Wilcoxon and

- Mantel-Haenszel.

This paper aims to analyse the reliability and durability in terms of the limit values of the abrasive wear of structural materials used for working parts processing abrasive soil pulp. Multi-dimensional analyses have been applied as the analytical tools to allow the identification of wear of the materials studied, taking into account:

- division into similar groups as an introduction to further multidimensional analyses;

- relationships between categories of variables, including the qualitative variables;

- influence of confounding factors (soil pulp type) on the reliability of the models determined.

\section{Laboratory tests}

\subsection{Objective and scope of the study}

The objective of the studies performed was to obtain details of the abrasive wear process depending on the hardness of the top layers of the materials examined, their structure, chemical composition and soil type.

The materials were tested in abrasive soil pulp with particle sizes as described in Table 1. The tests were performed on 21 types of materials listed in Table 2. Wear measurements were performed every $4 \mathrm{~km}$ of friction path, up to $20 \mathrm{~km}$. The number of repetitions was 5 specimens for every material. The wear values adopted in further analyses are the average values of five tests.

\subsection{Test bench}

To study the wear pattern of top layers in diverse soil conditions, the laboratory test bench as shown in Fig. 2 was used.

The machine comprises a rotary bowl and two abrading sections enabling oscillating movement. Work processes of the section are monitored and controlled by the PLC V350-35-R2 controller. Software has been downloaded to the controller memory that allows for:

- precise setting of the friction path;

- selection of movement type (with/without oscillation);

- measurement and recording friction forces for both sections independently;

- measurement and recording of friction path covered;

- measurement and recording of moisture content and temperature of abrasive pulp;

- declaration of linear velocity of abraded specimens;

- declaration of oscillation velocity;

- controlling the moisture content of the abrasive pulp. 
Table 1. Description of abrasive soil pulp

\begin{tabular}{||c|c|c|c|c|c||}
\hline $\begin{array}{c}\text { Soil descrip- } \\
\text { tion }\end{array}$ & Type & $\begin{array}{c}\text { Sand } \\
\mathbf{1}+\mathbf{0 . 1} \mathbf{~ m m} \\
{[\%]}\end{array}$ & $\begin{array}{c}\text { Dust } \\
\mathbf{0 . 1 \div 0 . 0 2} \mathbf{~ m m} \\
{[\%]}\end{array}$ & $\begin{array}{c}\text { Floating parts } \\
<0.02 ~ \mathbf{~ m m} \\
{[\%]}\end{array}$ & $\begin{array}{c}\text { Moisture } \\
\text { content by } \\
\text { weight }\end{array}$ \\
\hline Heavy clay & Normal clay & 33.62 & 49.92 & 16.56 & {$[\%]$} \\
\hline Light soil & Loamy sand & 77.48 & 20.83 & 1.69 & 8 \\
\hline Medium soil & Light clay & 52.66 & 40.32 & 7.02 & 12 \\
\hline
\end{tabular}

\section{Results of tests and analysis}

\subsection{Chemical composition, structure and hardness}

The results of testing the chemical composition, structure and hardness of layers pad-welded with a covered electrode are listed in Table 3, and the characteristics of other materials can be found in [12].

The results presented are only a part of comprehensive tests (of the chemical composition,
Table 2. List of materials studied

\begin{tabular}{|c|c|c||}
\hline Steels & Pad-welded layers & Carbide layers \\
\hline 38GSA & El-Hard 61 & Carbide B 26 \\
\hline B27 & El-Hard 63 & Carbide G 10 \\
\hline Hardox 500 & El-Hard 65 & \\
\hline Hardox 600 & El-Hard 67 & \\
\hline Tbl Plus & El-Hard 70 & \\
\hline XAR 600 & F-600 TiC & \\
\hline & F-61 & \\
\hline & F-64 & \\
\hline & F-65 & \\
\hline & F-67 & \\
\hline & F-78 & \\
\hline & XHD 6710 & \\
\hline & XHD 6715 \\
\hline
\end{tabular}

The operating algorithm of the test bench for studying wear in abrasive soil pulp is shown in Figure 3.

A JEOL JSM - 5800 LV scanning microscope coupled with the Oxford LINK ISIS - 300 X-ray radiation micro-analyser was used for micro-analyses of chemical composition.

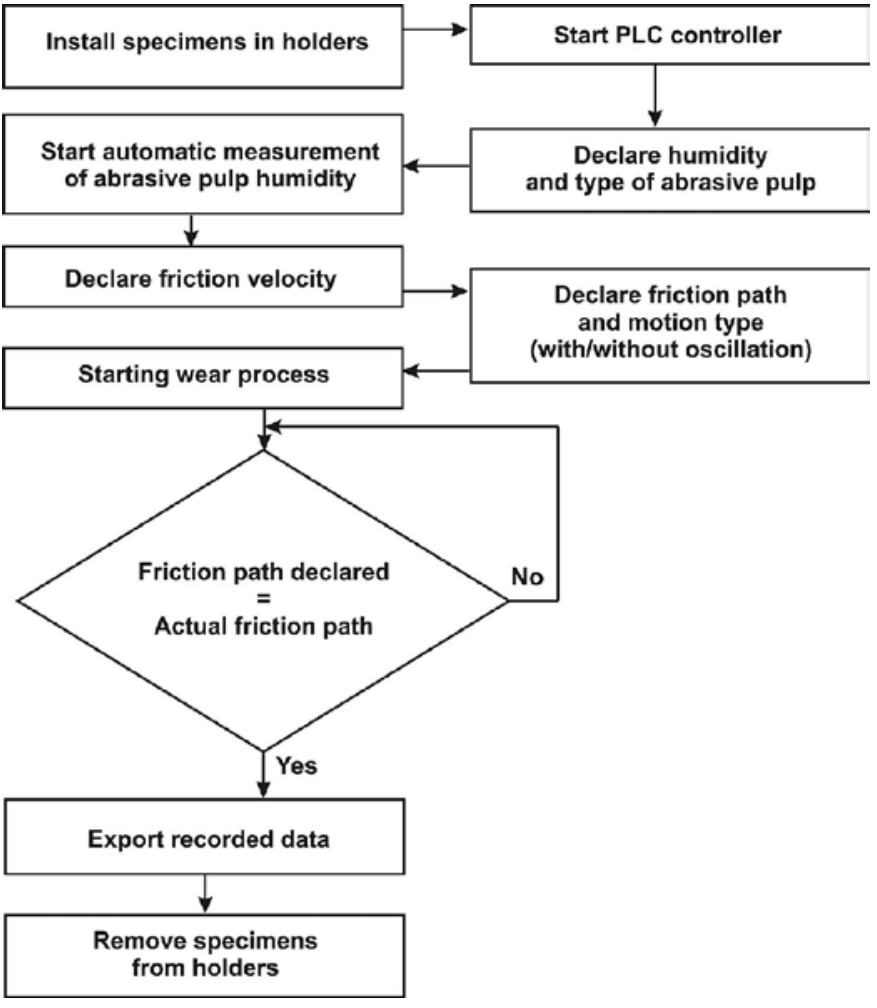

Fig. 3. Operating algorithm of the test bench for studying wear in abrasive soil pulp

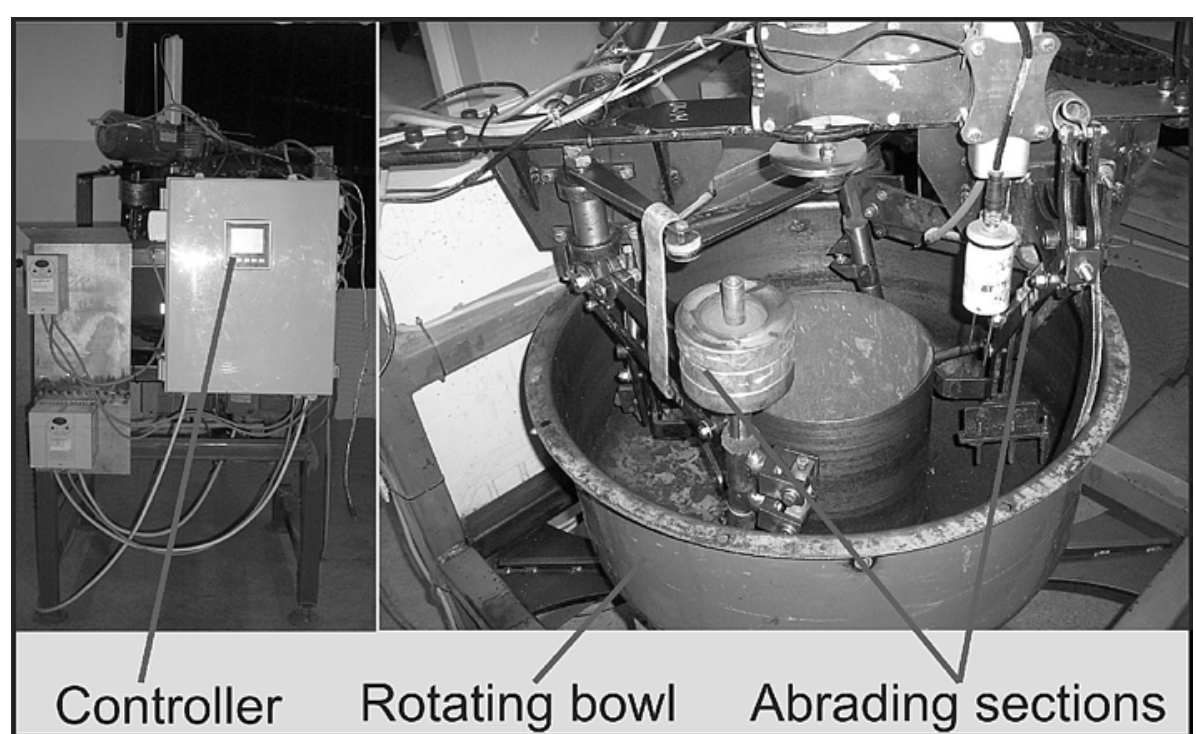

Fig. 2. Machine for testing wear in abrasive soil pulp structure and hardness), while in the examples of multi-dimensional analyses given, all results have been used correspondingly for the purpose defined.

\subsection{Identification of similar groups}

The cluster analysis was employed for the identification of similar construction materials. The major concept underlying the cluster analysis is to distribute objects in a certain number of (predefined or not) groups of 'similar' objects which, at the same time, are not 'similar' to objects from the other groups. It is assumed that such grouping can contribute much to the exploration of the structure of factors affecting the wear patterns, in particular:

- to detect if the clusters obtained indicate any regularity, e.g. relationships between the material hardness and wear;

- reduce a large data set to averages of the individual groups;

- treat the division into groups as an introduction to further multi-dimensional analyses. 
Table 3. Characterisation of top layers pad-welded with covered electrodes

\begin{tabular}{|c|c|c|c|c|c|c|c|c|c|c|c|}
\hline Material & C & Tn & $\mathrm{Cr}$ & Mo & B & w & v & $\mathrm{Ti}$ & $\mathrm{Nb}$ & Structure & $\begin{array}{l}\text { Hardness } \\
\text { HV10 }\end{array}$ \\
\hline El-Hard 61 & 5.2 & 1.2 & 29.0 & 0.7 & - & - & - & - & 7.0 & $\begin{array}{l}\text { Alloy ferrite transitioning to the structure composed } \\
\text { of alloy ferrite and carbide phases (ledeburite struc- } \\
\text { ture). Microstructure of a layer pad-welded with } \\
\text { precipitates of chromium and niobium carbides. }\end{array}$ & 632 \\
\hline El-Hard 63 & 5.0 & - & 34.0 & - & - & - & - & - & - & $\begin{array}{l}\text { Padding weld microstructure. Great precipitates of } \\
\text { primary carbides type } \mathrm{M} 7 \mathrm{C} 3(\mathrm{Fe}, \mathrm{Cr} 7 \mathrm{C} 3) \text { on the back- } \\
\text { ground of alloy ferrite and carbide mixture. Hypereu- } \\
\text { tectic } \mathrm{Fe}-\mathrm{Cr}-\mathrm{C} \text { alloy with ledeburite structure. }\end{array}$ & 658 \\
\hline El-Hard 65 & 4.5 & - & 24.0 & 6.0 & - & 2.0 & 1.0 & - & 6.0 & $\begin{array}{l}\text { Mixture of alloy ferrite and } \mathrm{M} 7 \mathrm{C} 3 \text { carbides - } \\
{[\mathrm{Fe}, \mathrm{Cr} 7 \mathrm{C} 3] \text { and niobium carbides. }}\end{array}$ & 682 \\
\hline El-Hard 67 & 5.0 & - & 23.0 & - & - & - & 10.0 & - & - & $\begin{array}{l}\text { Alloy ferrite with carbides (with ledeburite mixture } \\
\text { structure) with irregularly distributed primary pre- } \\
\text { cipitates of chromium carbides and fine, dark vana- } \\
\text { dium carbides. }\end{array}$ & 720 \\
\hline El-Hard 70 & 5.0 & 1.0 & 38.0 & 1.5 & 3.50 & - & - & - & - & $\begin{array}{l}\text { Large, locally fragmented precipitates of primary } \\
\text { chromium carbides with minute boron carbides. The } \\
\text { matrix constitutes ledeburite mixture composed of } \\
\text { alloy ferrite and minute carbides. }\end{array}$ & 776 \\
\hline XHD 6710 & 1.2 & 13.2 & 45.0 & - & - & - & - & - & - & $\begin{array}{l}\text { Large primary precipitates of chromium carbides on } \\
\text { the background of alloy ferrite+carbide mixture. }\end{array}$ & 795 \\
\hline XHD 6715 & 5.0 & - & 21.0 & 8.5 & - & 6.0 & 1.5 & - & 7.0 & $\begin{array}{l}\text { Large precipitates of primary chromium carbides in } \\
\text { alloy ferrite matrix and niobium carbides. Also slight } \\
\text { areas of ledeburite visible. }\end{array}$ & 820 \\
\hline
\end{tabular}

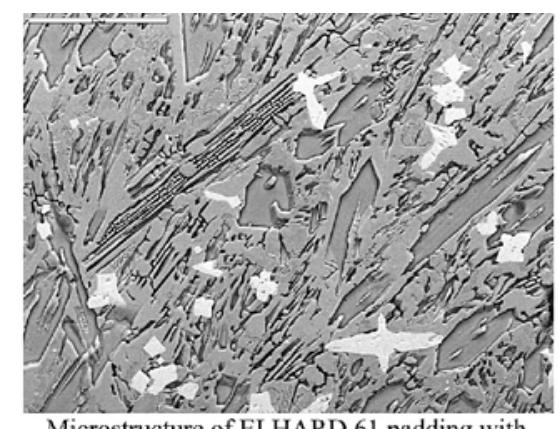

Microstructure of ELHARD 61 padding with precipitates of chromium (grey) and niobium (white) carbides

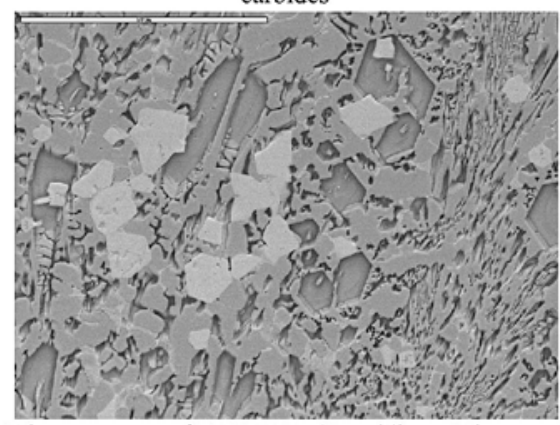

Microstructure of ELHARD 65 padding. Mixture of alloy ferrite and $\mathrm{M} 7 \mathrm{C} 3$ carbides $-[\mathrm{Fe}, \mathrm{Cr} 7 \mathrm{C} 3]$ and niobium carbides

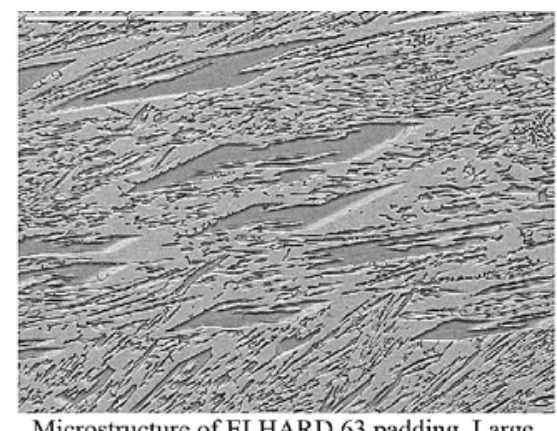

Microstructure of ELHARD 63 padding. Large precipitates of chromium carbides in the alloy ferrite + carbide matrix

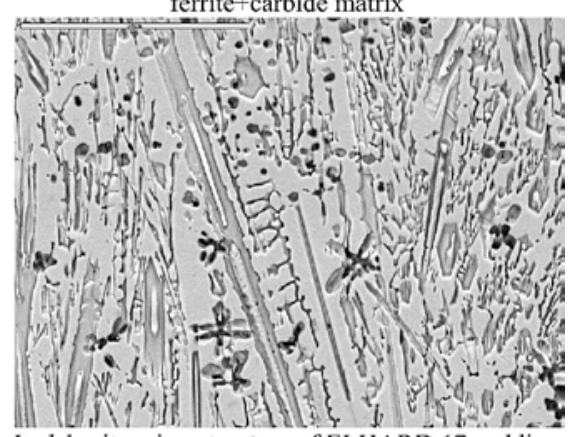

Ledeburite microstructure of ELHARD 67 padding with precipitates of chromium carbides (type M7C3) and vanadium carbides

applied, in which the distance between clusters equals the longest distance between any two objects belonging to various clusters. Using this method is justified when the objects are expected to naturally form specific 'clumps'. As a function of distance, the euclidean distance was chosen.

The sample data (Table 4) come from laboratory wear tests of 21 materials in light soil. As variables influencing the clusters, unit wear was used, expressed as $\left(\mathrm{g} \cdot \mathrm{cm}^{-2} \cdot \mathrm{km}^{-1}\right)$, and hardness HV10, hence the analysis aims at grouping materials in groups characterised by similar abrasive wear and hardness.

Before analysing the clusters the variables were standardised. For a single analysis the standardisation is not that important, but when several results of the cluster analysis are to be compared (e.g. for heavy, medium and light soil) this procedure enables the comparison of various dendrograms, and the distances between clusters will preserve a constant scale. Figure 5 shows the results of the cluster analysis in the form of a horizontal dendrogram.

It should be noted that initially each material forms its own cluster. As a horizontal dendrogram is analysed in the right direction, the materials which are 'close' one to another agglomerate in the following clusters. Based on the above it can be stated that the closest properties are found in the paddings F65 and XHD 6710 as

The cluster analysis includes several different algorithms for object classification $[18,19]$. In the example presented the agglomeration method was employed, in which hierarchically ordered clusters are obtained which can be presented in the form of a tree (dendrogram) showing distances between the grouped objects. To determine the distances between new clusters the complete linkage method was

well as in F61 and F64. On the other hand, the carbides are extremely different compared to all other materials. The results of the cluster analysis make it possible to relatively easily choose specific clusters (e.g. those with considerable wear resistance), and the relevant data can be further processed based on the chemical composition or struc- 
Table 4. Data for cluster analysis in light soil

\begin{tabular}{|c|c|c|c||}
\hline & Material & Hardness HV10 & $\begin{array}{c}\text { Wear after } 20 \mathrm{~km}_{\text {of friction }} \\
\text { path }\left[\mathrm{cm}^{-2} \cdot \mathrm{km}^{-1}\right]\end{array}$ \\
\hline 1. & $38 G S A$ & 414 & 0.0160 \\
\hline 2. & B27 & 549.7 & 0.0155 \\
\hline 3. & El-Hard 61 & 632 & 0.0032 \\
\hline 4. & El-Hard 63 & 658 & 0.0018 \\
\hline 5. & El-Hard 65 & 682 & 0.0023 \\
\hline 6. & El-Hard 67 & 720 & 0.0024 \\
\hline 7. & El-Hard 70 & 776 & 0.0010 \\
\hline 8. & F-600 TiC & 680 & 0.0040 \\
\hline 9. & F-61 & 779 & 0.0026 \\
\hline 10. & F-64 & 786 & 0.0023 \\
\hline 11. & F-65 & 824 & 0.0019 \\
\hline 12. & F-67 & 846 & 0.0013 \\
\hline 13. & F-78 & 874 & 0.0013 \\
\hline 14. & Hardox 500 & 567.3 & 0.0060 \\
\hline 15. & Hardox 600 & 554.1 & 0.0028 \\
\hline 16. & Tbl Plus & 578.8 & 0.0037 \\
\hline 17. & Carbide B 26 & 1818 & 0.0011 \\
\hline 18. & Carbide G 10 & 1430 & 0.0014 \\
\hline 19. & XAR 600 & 627.2 & 0.0020 \\
\hline 20. & XHD 6710 & 795 & 0.0018 \\
\hline 21. & XHD 6715 & 820 & 0.0013 \\
\hline & & & \\
\hline
\end{tabular}

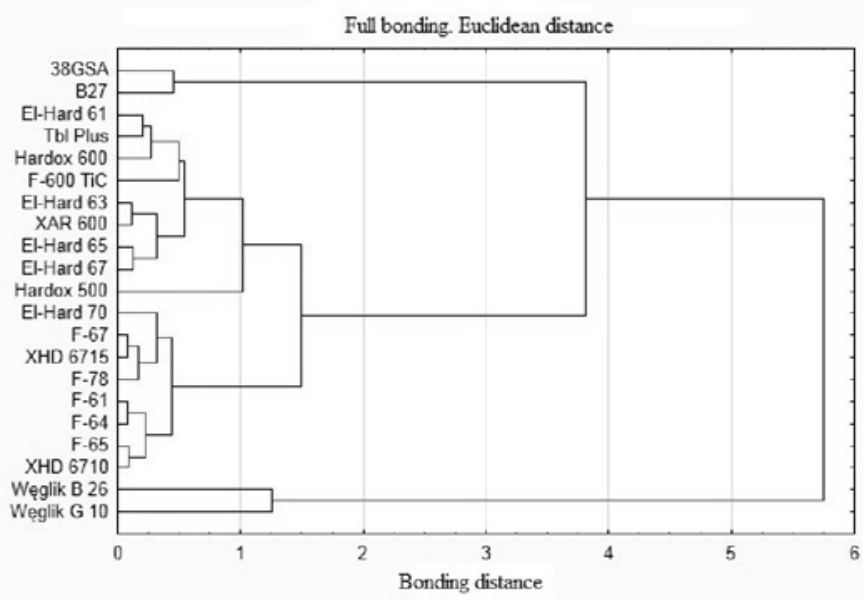

Fig. 5. Dendrogram for material clusters relative to wear and hardness in light soil

ture of only those materials so as to identify their values which account for favourable operating properties.

\subsection{Identification of links between variable categories}

Multiple reliability tests require qualitative variables to be analysed (nominal and ordinal), e.g. the soil type and materials structure. A starting point to analyse such data is to compile it in a contingency table. Common statistical techniques (chi-square, V Cramera, O-Yula, contingency factor) provide information only on the significance and strength of links between qualitative variables, but they do not describe the nature of links between categories of the qualitative variables analysed. Therefore, another analysis employed to identify resistance to abrasive wear is correspondence analysis, providing information that is similar in interpretation to the results of factor analysis, relating, however, to the qualitative variables. An analysis of the statistics and charts used in the correspondence analysis enables simple and intuitive inference about the links present between the categories of variables. Therefore, the main purpose of the correspondence analysis is to present the analysed set of points in a maximum 3D space, maintaining complete or nearly complete information on the variability of the matrix model lines. The singular value decomposition method (SVD) was employed to solve this problem [4, 17].

The most common way to present the effects of the correspondence analysis performed is the graphic presentation of the simultaneous occurrences of variable categories. The resulting chart is referred to as the map of correspondence. Interpretation of the results obtained consists in assessing the location of points depicting variable categories on the chart. Three components have to be taken into account [20]:

- point location relative to the centre of projection (axes intersection point);

- point location relative to other points determining categories belonging to the same feature;

- point location relative to the point describing a category of a different feature.

In the determination of the effect of a construction material on abrasive resistance, there are virtually no numerical data available (percentage of its components), but only information about the occurrence of individual structure types in the 'present' or 'absent' categories. It is therefore impossible to employ modelling based on factor analysis. This is possible with correspondence analysis, and thus it was decided to employ it to determine links between the structure of 21 materials examined, and wear intensity (Table 5). The data come from 57 wear tests. The map of abrasive wear correspondence depending on material structure is shown in Figure 6.

Ana $=y$ sing the map of correspondence, the following conclusions can be drawn:

- the occurrence of ferrite structure combined with secondary and primary carbides is beneficial - this leads to satisfactory or acceptable wear;

- the occurrence of perlite can be beneficial for the reduction of abrasive wear. Note, however, the very low values of 'weight' and 'quality' of that point - this condition requires a more indepth study (statistical weight and quality index are applied in the correspondence analysis to determine the strength of the links between the features examined [1]);

- martensite and troosite clearly belong to the group of increased and unacceptable wear. Materials with this structure should be avoided when selecting structural material for the working parts of soil processing equipment.

Table 5. Data for correspondence analysis

\begin{tabular}{||c|c|c|c|c|c|}
\hline $\begin{array}{c}\text { Material structure } \\
\text { composition }\end{array}$ & $\begin{array}{c}\text { Symbol in the map } \\
\text { of correspondence }\end{array}$ & $\begin{array}{c}\text { Satisfac- } \\
\text { tory wear } \\
Z_{1}\end{array}$ & $\begin{array}{c}\text { Accept- } \\
\text { able wear } \\
Z_{2}\end{array}$ & $\begin{array}{c}\text { Increased } \\
\text { wear } \\
Z_{3}\end{array}$ & $\begin{array}{c}\text { Unaccept- } \\
\text { able wear } \\
Z_{4}\end{array}$ \\
\hline Martensite & $\mathrm{M}$ & 0 & 0 & 9 & 9 \\
\hline Troostite & $\mathrm{T}$ & 0 & 0 & 0 & 9 \\
\hline Ferrite & $\mathrm{F}$ & 18 & 21 & 0 & 3 \\
\hline Primary carbides & $\mathrm{Wp}$ & 24 & 12 & 0 & 0 \\
\hline $\begin{array}{c}\text { Secondary car- } \\
\text { bides }\end{array}$ & $\mathrm{Ww}$ & 24 & 18 & 3 & 3 \\
\hline Perlite & $\mathrm{P}$ & 0 & 6 & 0 & 0 \\
\hline
\end{tabular}




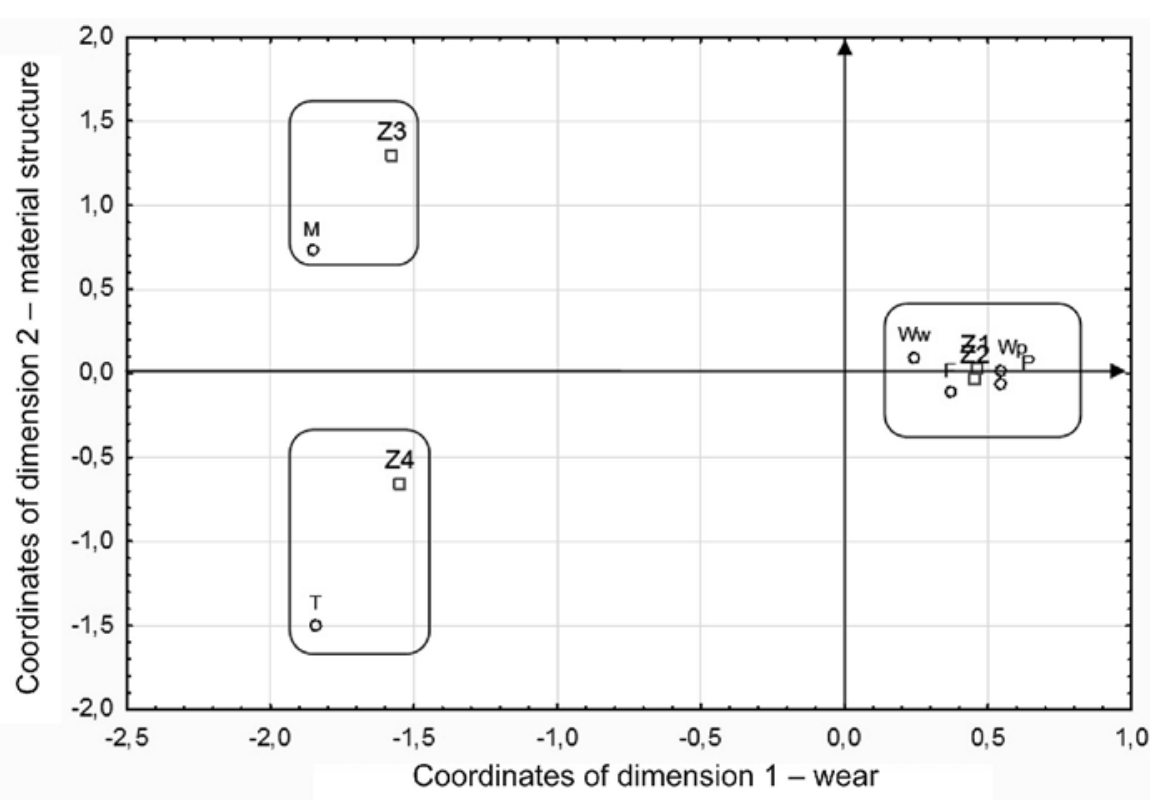

- Points representing material structure

$\checkmark$ Points representing wear

$L_{j}-$ number of samples not exceeding wear limits (for both materials);

$N_{j}$ - size of the $\mathrm{j}^{\text {th }}$ category.

With the above symbols the following (general) zero hypothesis can be formulated:

$\mathrm{H}_{0}: p_{11}=p_{12}, p_{12}=p_{22}, \ldots, p_{1 k}=p_{2 k}$

where: $p_{i j}$ is the probability of excessive wear in the $i^{\text {th }}$ group and the $j^{\text {th }}$ category. The Mantel and Haenszel test enables a simultaneous (in $k$ categories) probabilistic comparison of fallibility (or reliability) in the groups analysed. To verify the hypothesis so formulated, the chisquare statistic method with the following form is applied:

$$
M H_{i}=\frac{\left(\sum_{j=1}^{k} z_{i j}-\sum_{j=1}^{k} E\left(z_{i j}\right)-1\right)^{2}}{\sum_{i=1}^{k} \operatorname{VAR}\left(z_{i j}\right)},
$$

where: $E\left(z_{\ddot{y}}\right)$ - expected number of excessively worn samples for the $i^{\text {th }}$ material and the $j^{\text {th }}$ category, $\operatorname{VAR}\left(z_{\ddot{j}}\right)$ - variance of excessively

\subsection{Influence of confounding factors}

Field tests often tend to compare reliability for several groups of objects, in which the influence of additional factors, referred to as confounding variables, has to be considered. For example, comparing the effect of two pad-welding methods on the reliability (or durability) of working parts operating in abrasive soil pulp, confounding variables including soil moisture content, particle size distribution, friction velocity, etc. can be taken into account. In such situations the method proposed by Mantel and Haenszel [20] can be applied. The test developed by them is based on an analysis of $2 \times 2$ tables (e.g. type of padding vs. reliability), divided by another classifying variable (confounding variable - e.g. soil type).

Table 6. General example of a contingency table assuming two material types

\begin{tabular}{|c|c|c|c||}
\hline $\begin{array}{c}\text { Padding mate- } \\
\text { rial type }\end{array}$ & $\begin{array}{c}\text { Number of ex- } \\
\text { cessively worn } \\
\text { samples }\end{array}$ & $\begin{array}{c}\text { Number of samples } \\
\text { not exceeding wear } \\
\text { limits }\end{array}$ & Total \\
\hline Material 1 & $\mathrm{z}_{1 \mathrm{j}}$ & $\mathrm{n}_{1 \mathrm{j}} \mathrm{z}_{1 \mathrm{j}}$ & $\mathrm{n}_{1 \mathrm{j}}$ \\
\hline Material 2 & $\mathrm{z}_{2 \mathrm{j}}$ & $\mathrm{n}_{2 \mathrm{j}} \mathrm{z}_{2 \mathrm{j}}$ & $\mathrm{n}_{2 \mathrm{j}}$ \\
\hline Total & $\mathrm{Z}_{\mathrm{j}}$ & $\mathrm{L}_{\mathrm{j}}$ & $\mathrm{N}_{\mathrm{j}}$ \\
\hline
\end{tabular}

Let $k$ denote the category number of the confounding variable. Then, for every category $j(j=1,2, \ldots, k)$ contingency tables can be considered (Table 6). The number of tables created depends on the size of category $k$.

In table 4 the following symbols are assumed:

$z_{l j} \quad-$ number of samples worn excessively in the $j^{\text {th }}$ category for material 1 ;

$z_{2 j} \quad$ - number of samples worn excessively in the $j^{\text {th }}$ category for material 2 ;

$n_{l j}, n_{2 j}$ - sizes for materials 1 and 2, respectively;

$Z_{j} \quad-$ number of samples worn excessively in the $j^{\text {th }}$ category (for both materials);
Table 7. Data to compare two material groups

\begin{tabular}{||c|c|c|c|c||}
\hline \multirow{2}{*}{$\begin{array}{c}\text { Friction path } \\
{[\mathrm{km}]}\end{array}$} & $\begin{array}{c}\text { Group 1 } \\
\begin{array}{c}\text { Number of ex- } \\
\text { cessively worn } \\
\text { samples }\end{array}\end{array}$ & $\begin{array}{c}\text { Number of sam- } \\
\text { ples not exceed- } \\
\text { ing wear limits }\end{array}$ & $\begin{array}{c}\text { Number of ex- } \\
\text { cessively worn } \\
\text { samples }\end{array}$ & $\begin{array}{c}\text { Number of sam- } \\
\text { ples not exceed- } \\
\text { ing wear limits }\end{array}$ \\
\hline 4 & 0 & 40 & 1 & 29 \\
\hline 8 & 2 & 38 & 2 & 27 \\
\hline 12 & 3 & 35 & 7 & 20 \\
\hline 16 & 5 & 30 & 7 & 13 \\
\hline 20 & 12 & 18 & 10 & 3 \\
\hline
\end{tabular}


Table 8. Contingency tables (material type $\times$ soil type)

\begin{tabular}{|c|c|c|c|c|c|c|}
\hline \multirow[b]{2}{*}{$\begin{array}{l}\text { Material } \\
\text { type }\end{array}$} & \multicolumn{3}{|c|}{ Light soil } & \multicolumn{3}{|c|}{ Medium soil } \\
\hline & $\begin{array}{c}\text { Number of excessively } \\
\text { worn samples after } 20 \mathrm{~km} \\
\text { of friction path }\end{array}$ & $\begin{array}{l}\text { Number of samples not } \\
\text { exceeding wear limits }\end{array}$ & Total & $\begin{array}{c}\text { Number of excessively } \\
\text { worn samples after } 20 \mathrm{~km} \\
\text { of friction path }\end{array}$ & $\begin{array}{l}\text { Number of samples not } \\
\text { exceeding wear limits }\end{array}$ & Total \\
\hline Group 1 & 12 & 18 & 30 & 10 & 17 & 27 \\
\hline Group 2 & 10 & 3 & 13 & 7 & 5 & 12 \\
\hline Total & 22 & 21 & 43 & 17 & 22 & 39 \\
\hline
\end{tabular}

lowing results were obtained: $M H=19.1626 ; p=0.00001 ; R W=0.27101$. Therefore, it has to be concluded that there is a significant difference between the distributions examined $(p<0.0001)$. The value of the risk index RW of 0.27 can be interpreted as follows: in about $70 \%$ of cases the limit wear of the second material group will be reached earlier (at a shorter friction path) as compared to the other group.

Further studies were conducted taking into consideration the confounding variable (soil type). The data for analysis are shown in contingency tables $2 \times 2$ (Table 8 ).

The results of calculations according to formulas 2 and 3 are the following: $M H=8.47$ ( $p=0.0036) ; R W=0.29$. In this case the zero hypothesis also has to be rejected. This means that the soil type is considerably related to the wear rate. Note, however, that the calculated value $p$ is much greater than in the previous example, so the significance of the influence of soil type on the durability and reliability of working parts processing the soil is not as dominating as the type of the construction material.

\section{Summary and conclusions}

A phenomenon accompanying the operation of working parts in soil pulp as intense wear, which is an effect of physiochemical qualitative and quantitative changes taking place at the friction surface. The process of intense wear in soil occurs in the working parts of agricultural, construction, road construction and mining machinery. Among these components the greatest wear intensity is found in the working parts of cultivating equipment. It was proven that the weight loss depends on the structural material and condition of the soil pulp. The examples presented demonstrate the usefulness of multi-dimensional analyses in the modelling of abrasive wear and in reliability analyses.

Cluster analysis was found to be extremely useful in grouping structural material types with similar resistance to abrasion. The identification of similar groups is simple and intuitive based on cluster dendrograms. To give an example, the following similar material groups were identified:

- XHD 6710, F61, F64, F65;

- XHD 6715, F-67, F-78;

- 38GSA, B27;

- carbides B26 and G10.
Analysis of correspondence enabled the grouping of qualitative characteristics, and answered the question about the structure of construction material that leads to increased or decreased wear. A graphical presentation (in the form of a correspondence map) is helpful in the interpretation of the results obtained. Furthermore, the values of 'weight' and 'quality' parameters give an indication of the importance of individual variables and the degree (quality) of identification of the conditions being studied by the qualitative variables. The results of the correspondence analysis allow for the following conclusions:

- the presence of a ferrite structure combined with secondary and primary carbides increases the durability of working parts;

- the presence of perlite can be beneficial to the reduction of abrasive wear. However, this has not been fully proven because of the low values of the 'weight' and 'quality' indicators for such structures;

- martensite and troosite content in the material considerably reduces the reliability of working parts.

The application of the Mantel and Haenszel analysis made it possible to identify the significance of influence of soil type and material types on the wear rates, whereby the type of the construction material was found to affect the reliability of those parts more.

The analyses described herein can be performed in multiple variants, for various types of materials and soil conditions. This gives rise to the selection of data, based on which reliability models can be built. For example, the conditional Bayes model is the one that allows for forecasting wear in abrasive soil pulp. The usefulness of this model is particularly important in the determination of the limit condition, provided that friction is present in the defined forces of abrasive soil pulp. This procedure allowed for the application of the Bayes estimator of friction path, and determined beforehand the probability of reaching the limit values depending on the friction path.

The initial selection of experimental data also appears to be useful in modelling the wear process with the Weibull distribution. A very good match of this model is achieved for the shape parameter value: $k=2$, and scale: $\gamma=1$. For model parameters selected in this way it is possible to forecast the wear of steel with boron content in abrasive soil pulp groups considered as homogeneous, for their influence on the intensity of wear.

\section{References}

1. Adamiak M, Górka J, Kik T. Comparison of abrasion resistance of selected constructional materials. Journal of Achivements and Manufactoring Enginering 2009; 37: 375-380.

2. Baba Zadeh M, Pour Asiabi H. Wear Characteristics of ADIs; A Comprehensive Review on Mechanisms and Effective Parameters. Journal of Basic and Applied Scientific Research 2013; 3(2): 646-656.

3. Badisch E, Winkelmann H, Franek F.: Hightemperature continuous impact abrasion testing (HAT-CIAT): Wear behaviour of single and multiphase materials up to $750{ }^{\circ} \mathrm{C}$. 18th International Baltic Conference on Engineering Materials \& Tribology - BALTMATTRIB Talin 2009; 22-23.

4. Bénzecri J P. Correspondence Analysis Handbook. New York: Marcel Dekker Inc, 1992.

5. Buchely M F, Gutierrez J C, Le' on L M, Toro A.. The effect of microstructure on abrasive wear of hardfacing alloys. Wear 2005; 259: 52-61, http://dx.doi.org/10.1016/j.wear.2005.03.002.

6. Čikara D, Rakin M, Todić A. Cast Steel-SiC Composites as Wear Resistant Materials. FME Transactions 2009; 37: 151-155. 
7. Fernández J E, Vijande R, Tucho R, Rodriguez J, Martin A. Materials selection to excavator teeth in mining industry. Wear 2001; 250: 11-18, http://dx.doi.org/10.1016/S0043-1648(01)00624-X.

8. Gatnar E, Walesiak M. Metody statystycznej analizy wielowymiarowej w badaniach marketingowych. Wrocław: Wydawnictwo Akademii Ekonomicznej, 2004.

9. Goel G, Cherukuri H P, Toro A. A Numerical Study of Abrasive Wear in Tillage Tools due to Soil-Tool Interaction. SIMULIA Customer Conference held at Rhode Island Convention, 2012.

10. Morison D F. Wielowymiarowa analiza statystyczna. Warszawa: PWN, 1990.

11. Nalbant M, Palali A T. Effects of diff erent material coatings on the wearing of plowshares in soil tillage. Turkish Journal of Agriculture and Forestry 2011; 35: 215-223.

12. Napiórkowski J (Red), Drożyner P, Kołakowski K, Ligier K, Mikołajczak P, Rychlik A, Szczyglak P. Badania i modelowanie procesów zużywania ściernego i zmęczeniowego. Olsztyn: Wydawnictwo UWM, 2014.

13. Napiórkowski J, Pękalski G, Kołakowski K. Badanie struktur i zużywania powłok napawanych w glebowej masie ściernej. Tribologia 2012; 3: $111-118$.

14. Pękalska L, Pękalski G. Budowa fazowa i struktury napoin stosowanych w górnictwie węgla brunatnego. Węgiel Brunatny 2000; wyd. specjalne: 86-91.

15. Perez M J , Cisneros M M, Lopez H F,: Wear resistance of Cu-Ni-Mo austempered ductile iron. Wear 2006; 260: 879-885, http://dx.doi. org/10.1016/j.wear.2005.04.001.

16. Powierża A L. Elementy inżynierii systemów. Warszawa: Wydawnictwo Politechniki Warszawskiej, 1997.

17. Stanimir A. Wykorzystanie analizy korespondencji w badaniach marketingowych. StatSoft Polska. 2008 www.statsoft.pl/czytelnia (dostęp 01.03.2013 r.).

18. Stanisz A. Przystępny kurs Statystyki w oparciu o program Statistica PL na przykładach z medyny. Tom 3. Analizy wielowymiarowe. Kraków: StatSoft, 2007.

19. StatSoft . Elektroniczny Podręcznik Statystyki PL, Kraków, 2006. http://www.statsoft.pl/textbook/stathome.html.

20. Stoma M. Modele i metody pomiaru jakości. Lublin: Q\&R Polska, 2012.

21. Verma A, Gopinatha K, Sarkarb S B. Boron Steel: An Alternative for Costlier Nickel and Molybdenum Alloyed Steel for Transmission Gears. The Journal of Engineering Research 2011; 8 (1): 12-18.

22. Wang Q, Li X. Effects of Nb, V, and W on microstructure and abrasion resistance of Fe-Cr-C hardfacing alloys. Welding Journal 2010; 89: 133-139.

\section{Paweł MIKOŁAJCZAK \\ Jerzy NAPIÓRKOWSKI}

Faculty of Technical Sciences

University of Warmia and Mazury in Olszytn

ul. Oczapowskiego 11, 10-719 Olsztyn, Poland

E-mail: pawel.mikolajczak@uwm.edu.pl,napj@uwm.edu.pl 